\title{
ПLASHING CULTURAL \\ NATIONALISMS: THE 19TH-CENTURY \\ DANISH-GERMAN INTELLECTUAL \\ DEBATE, THE SCHLESWIG WARS (1848-1864), \\ AND SOME REFLECTIONS ON THE \\ CULTURAL ROOTS OF NATIONAL \\ SOCIALISM
}

\author{
Francesco La Rocca \\ Central European University, Budapest, \\ E-mail: laroccafrancescolarocca@gmail.com
}

\section{Acknowledgements}

This article represents the evolution of the contribution entitled "Cultural and Political Spaces in Conflict: The Danish-German Intellectual Conflicts and the Schleswig Wars (1848-1864)" presented at the 7th Annual Graduate Conference in European History "Historians in Space: Concepts of Space in Recent European Historiography" (Budapest, 25-27 April 2013). I am particularly grateful to Daniel Baric for his constructive advices and remarks on German cultural nationalism. I am indebted to Borbála Klacsmann and György Szőnyi for their comments and suggestions. I should also like to extend my thanks to the American Research Center in Sofia for the Pre-Doctoral Fellowship (Autumn 2014) which facilitated the preparation of this article.

The publication of this paper is supported by EEA Grants, contract no 4/22.07.2014.

\footnotetext{
Abstract:

Romantic culture, far from only being an intellectual phenomenon, was a pivotal element in the 19th-century nation-building processes experienced in Europe, and it ended up influencing and being influenced by contemporary political events. The wars waged between Denmark and the German Confederation (1848-1864) are a foremost example of it, as the political claims for the control of the duchies of Schleswig, Holstein and Lauenburg intertwined with the intellectual polemics between some prominent German scholars (Jacob Grimm, Karl Müllenhoff etc.)
} 
who intended to prove the German nature of the duchies' cultural heritage and of Scandinavian cultures in general, and some Danish intellectuals (Nicolai Grundtvig, Rasmus Rask etc.) who strove to undo what they perceived as a politically-charged cultural aggression. The relevance of the Schleswig Wars and their related intellectual debate is not restricted to 19th-century studies, as some authors of the second half of the 20th century have suggested that the GermanDanish intellectual conflict over the heritage of the Old North was actually a prelude to what would eventually be Nazi Germany's totalitarian ideology. Unfortunately, little has been written so far on the relationship between the Schleswig Wars and the then-contemporary scholarly debate. This article is intended to be an effective contribution in this direction.

\section{Rezumat:}

Cultura romantică, departe de a fi doar un fenomen intelectual, a constituit un element esențial în procesele de construire a națiunii care s-au desfăşurat in Europa în sec. al XIX-lea și au sfârş̧it prin a influența și a fi influențate de evenimentele politice contemporane. Războaiele desfășurate între Danemarca și Confederația Germană (1848-1864) constituie un exemplu primordial al acestei afirmații, de vreme ce pretențiile politice pentru ducatele Schleswig, Holstein și Lauenburg s-au intrețesut cu polemicele intelectuale dintre câțiva savanți proeminenți germani (Jacob Grimm, Karl Müllenhoff etc.) care intenționau să dovedească natura germană a patrimoniului cultural al ducatelor și al culturilor scandinave, în general, și unii intelectuali danezi (Nicolai Grundtvig, Rasmus Rask etc.) care căutau să demonteze ceea ce percepeau a fi o agresiune culturală cu fundament politic. Relevanța Războaielor Schleswig-ului și dezbaterea intelectuală asociată acestora nu se rezumă la studiile cu privire la sec. al XIXlea, iar aşa cum au sugerat câțiva autori din a doua jumătate a sec. al XX-lea conflictul intelectual germano-danez asupra moștenirii vechiului Nord a fost de fapt preludiul a ceea ce va fi ideologia totalitară a Germaniei Naziste. Din păcate, s-a scris puțin despre relația dintre Războaiele Schleswig-ului și dezbaterea academică de atunci. Articolul de față își propune să-ş̧i aducă o contribuție efectivă în această direcție.

Keywords: Germany, Denmark, Schleswig Wars, cultural nationalism, National Socialism

\section{Introduction}

The two wars waged between Denmark and Prussia (1848-1950 and 1863-1864) for the control of the duchies of Schleswig (or Slesvig, according to Danish orthography), Holstein (Dan. Holsten) and Lauenburg (Dan. 
Lauenborg) represent a remarkable case of a $19^{\text {th }}$-century European conflict heavily influenced by Romantic-inspired nationalism, for the Prussian and Danish political claims over Schleswig-Holstein were mirrored by a quarrel between intellectuals of both sides over the position of the Scandinavian cultures vis-à-vis the German one. In fact, while Danish scholars advocated the Scandinavian roots of the duchies' heritage, German intellectuals strove to demonstrate its unequivocal Germanness or, in some extreme cases, the intrinsic German (as distinct from "Germanic") nature of the Scandinavian cultures as a whole. This topic, already relevant per se, acquires further importance as some scholars are prone to see a connection between Nazi Germany's aggressive nationalism and the expansionist claims that some German intellectuals laid to the Scandinavian cultural space at the time of the Schleswig Wars.

However, despite its potentiality, the Danish-German cultural debate has usually been relegated to a secondary role - mostly as a side topic for students of German and Scandinavian literatures. While the consequences of the Schleswig Wars in the 19th-century Danish cultural and political life have always been taken into account, ${ }^{1}$ a narrative of the $19^{\text {th }}$-century confrontation intellectual between Danes and Germans vis-à-vis the Schleswig Wars is lacking. This essay tries to partially obviate this situation, in the hope that further studies will be devoted to this crucial case of political and cultural nationalism: over the next pages, I will highlight the most relevant aspects of $19^{\text {th }}$-century struggle between Danish and German intellectuals for the Scandinavian cultural realm and its relationship with the Schleswig Wars, paying particular attention to the positions held by some of the most prominent Danish and German literates of the time and eventually addressing the thorny issue of the connection between German Romantic culture and National Socialism.

The Schleswig Wars have been studied by scholars of different intellectual backgrounds. One of the most complete account is William Carr's Schleswig-Holstein 1815-48: A Study in National Conflict ${ }^{2}$, a book which expands both on the conflict's political causes and on the role played by Romantic-inspired nationalism. More focussed on the wars' cultural roots

\footnotetext{
1 See for example Ib Fischer Hansen, Jens Anker Jørgensen, Knud Michelsen, Jørgen Sorensen, Lars Tonnesen (eds.), Litteraturhåndbogen (1985, reprint Copenhagen: Nordisk Forlag, 1992), 142-144.

2 William Carr, Schleswig-Holstein 1815-1848: A Study in National Conflict (Manchester: Manchester University Press, 1963).
} 
is Miroslav Hroch's seminal Social Preconditions of National Revival in Europe, which investigates how nationalism made its way among the different social strata of Schleswig's Danish society in 1840s and $1850 \mathrm{~s}^{3}$ - the only instance of a minority national movement in Hroch's study on national agitation among "smaller" European nations. By the same token, Alexa Geisthövel has provided another valid contribution with her Eigentümlichkeit und Macht. Deutscher Nationalismus 1830-1851: Der Fall Schleswig-Holstein, ${ }^{4}$ where she explores the different tendencies in German nationalism during the first Schleswig crisis, cunningly showing how German intellectuals and politicians were far from being a monolithic block, but rather encompassed different identification patterns and political aspirations which on their turn urged the elaboration of alternative solutions to the crisis.

Both these and other studies, however, mostly take into account the German and Danish "camps" separately, the reception of Romanticism in Denmark from Germans being the only interaction between the two cultures usually recounted. This provides a one-sided and inevitably partial picture of what was the German and Danish intellectual debate over the heritage of the Old North, for Scandinavian scholars too provided a relevant intellectual production which was on its turn received, if sometimes polemically, by their German colleagues. However, even though the relationship between the Schleswig Wars and the Danish-German cultural debate of the 19th century is still largely overlooked, there are a few studies touching upon this topic which provide some valuable food for thought. Among the most relevant publications which hint at the DanishGerman cultural confrontation shall be recalled Martin Arnold's Thor: Myth to Marvel, 5 a book which thoughtfully analyses the main features and reception history of the god of thunder's figure from the Middle Ages down to our days, reporting the positions and theories that many Scandinavian and German authors of the $19^{\text {th }}$ century had over the reception of the Norse heritage in general and Thor in particular. His

\footnotetext{
${ }^{3}$ Miroslav Hroch, Social Preconditions of National Revival in Europe: A Comparative Analysis of the Social Composition of Patriotic Groups among the Smaller European Nations, trans. Ben Fawkes (Cambridge: Cambridge University Press, 1985), 117-124.

4 Alexa Geisthövel, Eigentümlichkeit und Macht. Deutscher Nationalismus 1830-1851: Der Fall Schleswig-Holstein (Stuttgart: Franz Steiner Verlag, 2003).

5 Martin Arnold, Thor: Myth to Marvel (London/New York: Continuum International Publishing Group, 2011).
} 
analysis mostly focuses on the cultural realm, touching on the SchleswigHolstein crisis in a few occasions only. ${ }^{6}$ Mircea-Cristian Ghenghea, on the other hand, has extensively dealt with the Schleswig Wars in his recent analysis of $19^{\text {th }}$-century pan-Scandinavianism, where he fleshes out the crucial role this ideology played in the Nordic countries. ${ }^{7}$ However, this work mostly focuses on the political consequences of pan-Scandinavian tendencies, leaving the cultural aspect of pan-Scandinavianism somewhat in the background: consequently, a broad account of the $19^{\text {th }}$-century Danish-German intellectual and political contraposition between Danes and Germans remains yet to be done.

\section{Denmark, Prussia and the Two Schleswig Crises}

The wars which opposed the kingdoms of Denmark and Prussia (with a later involvement of Austria) between 1848 and 1864 are quite common knowledge and widely unfolded in the above-mentioned studies, therefore a brief recap should suffice here. The conflict had its roots in the early history of the border duchies of Schleswig and Holstein, this latter fief of the Holy Roman Empire but subjected to the Danish kings since the $12^{\text {th }}$ century, and indissolubly connected to Schleswig by King Christian I of Oldenburg in 1460. While Holstein was almost entirely German-speaking, Schleswig was heavily populated by Danes, the Germans dwelling mostly on its southern fringes. On the western coasts of Schleswig lived the Frisians, who enjoyed particular autonomy over judicial and financial matters. Up to the beginning of the $19^{\text {th }}$ century, the duchies were part of the vast Danish commonwealth, a composite state 8 which stretched from Norway to Iceland, Greenland, the Faroe Islands, the Caribbean islands of St. Thomas, St. John, and St. Croix, some expanses of the Gold Coast in today's Ghana until some small outposts in India. In the framework of this variegated political entity, the duchies were in personal union with Denmark, and in virtue of this juridical status the 1667 law which introduced royal succession through the female line in Denmark was not introduced in Schleswig-Holstein.

\footnotetext{
${ }^{6}$ Arnold, Thor, 117, 119, 127.

7 Mircea-Cristian Ghenghea, “About Pan-Scandinavianism. Reference Points in the 19th Century(1815-1864)", Revista Română de Studii Baltice și Nordice / The Romanian Journal for Baltic and Nordic Studies, Vol. 6, Issue 2 (2014): pp. 127-145.

8 Helmut Georg Koenigsberger, "Composite States, Representative Institutions and the American Revolution", Historical Research 62 (1989), 135-53.
} 
This situation changed dramatically after the Napoleonic Wars: Denmark, who aligned with France against Britain and her allies, was defeated and severely mutilated of her maritime empire by the loss of the commercial fleet and the Swedish annexation of Norway in 1814. In the meanwhile, the duchy of Holstein became part of the German Confederation in 1815.

In Denmark, the economic and political crisis following the war led to the creation of a vigorous liberal-nationalist movement, which in 1849 forced King Frederick VII (1808-1863) to give up the absolute power of the crown by signing the constitution. Among the various goals of the liberal movement the annexation of Schleswig to the kingdom was on the top of the list, for the incorporation of a region largely ethnically Danish would have, in their opinion, strengthened the Danish state - a typical 19th-century entanglement of liberal and nationalist instances. This idea was not really new, as it had been already cherished by the previous King Frederick VI (1768-1839) at the time of his regency but it was never put into practice. ${ }^{9}$ The implementation of the 1849 's constitution and the subsequent fear that Schleswig and Holstein would be separated and annexed to Denmark led first to protests and then to the rebellion of the German population of the duchies, thus causing the first Schleswig War (1848-1850).

The first conflict saw the Danes easily victorious over the rebels, as the support they first obtained from the German Confederation was soon withdrawn following British and Russian pressures (the latter being concerned about a possible territorial expansion of Prussia northward) - to the desperation of the German national movement. ${ }^{10}$ The London Protocol of 1852 returned the duchies to Copenhagen, with the proviso that the rights of the German population and the indivisibility of the duchies would be respected.

But in March 1863 the situation came to a head again, as the new King Christian IX (1815-1906) signed a new rendition of the constitution which provided for a stronger political integration of Schleswig into the Danish kingdom: this decision from Copenhagen eventually led to the outbreak of the second Schleswig War (1863-1864). This time the duchies, with the determinant support of Prussia and Austria, managed to definitively defeat the Danish troops. The Treaty of Vienna, signed on 30 October 1864, saw

\footnotetext{
9 See Carr, Schleswig-Holstein 1815-1848, 34-35.

${ }^{10}$ Edgar Joseph Feuchtwanger, Bismarck (London/New York: Routledge, 2002), 100.
} 
the undisputed victory of Prussia and her allies, and the duchies ended up being assigned to Austria and Prussia. Austria eventually lost her rights over Schleswig-Holstein Prussia (and then to the unified German state) following her defeat in the Austro-Prussian War of 1866, which led to the dissolution of the German Confederation. But in fact the conflict was not completely settled until 1920 when, after having resisted the cultural and linguistic assimilation pressures exerted by Berlin, the inhabitants of the northern part of Schleswig asked and obtained, via referendum, to be reunited with Denmark, who received these "new" territories under the name of Sønderjylland (South Jutland).

\section{The Cultural Struggle: The Quest of the Old North}

The conflict over the political space of Schleswig-Holstein was doubled by a long and at times heated debate between Danish and German scholars over the heritage of the Old North. It would be a tremendous mistake to regard the Danish-German intellectual debate of that time only as a straightforward scholarly war between two irremediably different civilisations. Quite the contrary, German culture has always played an important role in the Denmark, both due to geographical reasons and to the prominent influence of the German-speaking élite from SchleswigHolstein. The Romantic culture in the Scandinavian countries, which had Copenhagen as its main centre, was fostered by the contacts between exponents of German Romanticism with Danish intellectuals and artists. However, the rising of nationalism and the wars between Denmark and the German Confederation dramatically broadened the rift between the two parts, and the position of the old Scandinavian culture vis-à-vis the German one became one of the most debated topics.

The heritage of the Old North has been a matter of antiquarian interest among Scandinavian intellectuals since the $16^{\text {th }}$ century. Authors like the Danish Ole Worm (1588-1655), who in his RUNIR seu Danica literatura antiquissima (1636) gathered and translated into Latin several pieces of Old Norse poetry, devoted themselves to the study of Medieval runic sources and sagas in the effort to ennoble the heritage of the Scandinavian countries, so far regarded by many European intellectuals as a cultural backwater, by recovering the vestiges of their ancient literatures. ${ }^{11}$

11 Arnold, Thor, 80. 
The advent of Romanticism dramatically changed the scholarly approach to the heritage of the Old North. The new concept of the vernacular culture and its different embodiments (songs, legends, dances) as the key to understand the soul of a people, theorised and promoted by Johann Gottfried von Herder (1744-1803),12 introduced a new way to approach the national past. No more a mere object of old-fashioned antiquarian research, the study of the Norse culture gained actual political relevance.

Romanticism made its way from Germany to Denmark (and Norway) mostly thanks to the Norwegian intellectual of German and Danish descent Henrik Steffens (1733-1845). A pupil of Friedrich von Schelling (1755-1854) in Jena, Steffens is regarded as the harbinger of German philosophy in the Nordic lands. ${ }^{13}$ His arrival in Denmark in 1802 marked the beginning of a new era in Danish culture, for in the same year he both provided a young Adam Oehlenschlæger with the tenets of Romanticism during a 16-hour long meeting, ${ }^{14}$ and he started lecturing at the Valkendorffs Kollegium of the University of Copenhagen, where he found a proper environment where to spread the new cultural credo. Among the students who followed Steffens' classes was sitting a man who would eventually leave an indelible mark on $19^{\text {th }}$-century Danish culture: the poet, historian, pedagogue and Lutheran pastor Nikolai Frederik Severin Grundtvig (1783-1872). ${ }^{15}$

Grundtvig's figure stands out in Danish history due to his unceasing work for the education of the Danish people, his religious fervour in reforming the Protestant spirituality of the time and his patriotic activism. In his 1832's study Nordens Mythologi eller Sindbilled-Sprog, historisk-poetisk udviklet og oplyst (The Mythology or Symbolic Language of the North, a

\footnotetext{
12 For a comprehensive overlook on Herder's work see Hans Kohn, The Idea of Nationalism: A Study in Its Origins and Background (1944, reprint New Brunswick: Transaction Publishers, 2008), 427-452.

13 Steffen's role in the dissemination of Romanticism in Scandinavia can hardly be underestimated. As Edvard Beyer's clearly stated: "Det var Heinrich Steffens...som først brakte romantikken til Norden" (It was Henrik Steffens...who first brought Romanticism in the North. The English translation is mine.). Edvard Beyer (ed.), Norges litteraturhistorie. Bind 2: Fra Wergeland til Vinje (1975, reprint Oslo: J.W. Capellens Forlag, 1995), 36.

14 W. K. Stewart, "Oehlenschlæger and German Romanticism", Publications of the Society for the Advancement of Scandinavian Study, Vol. 2, No. 1 (October, 1914), 1-24.

15 For a thoughtful analysis of Grundtvig's literary and philosophical work see Steffen Auring, Søren Baggesen, Finn Hauberg Mortensen, Søren Petersen, Marie-Louise Svane, Erik Svendsen, Poul Aaby Sørensen, Jørgen Vogelius, Martin Zerlang, Dansk litteraturhistorie 5: Borgerlig enhedskultur 1807-48 (1984, reprint Copenhagen: Gyldendal, 2000), 62-91.
} 
Historical and Poetic Exposition and Explanation), Grundtvig recounted and reinterpreted the most important myths of the Nordic and Greek traditions: for him, the development of the new Danish society was intimately bound to the rediscovery of the spirit of the Norse and Greek mythologies corroborated by the 'Mosaic-Christian fundamental concept'. ${ }^{16}$ This positive influence of mythology over society, Grundtvig maintained, can only be obtained through education, therefore he included the study of mythology in the curriculum of his Folk High Schools (folkehøjskole), institutes devoted to the civic education of young Danish adults which would play a tremendous role in shaping the contemporary Danish national character. ${ }^{17}$

The outbreak of the first Schleswig War in 1848 deeply affected Grundtvig's life and work. Along with other Danish writers of the time (most notably Hans Christian Andersen), Grundtvig composed several war songs and poems which were to be distributed among the soldiers. But unlike most of his fellow writers, who dealt with topics which could be easily understood by the ordinary Danish soldier (often a poorly literate countryman) like love for the fatherland and the king, homesickness and gallantry on the battlefield, Grundtvig's poems sang the deeds of ancient Danish kings and stories taken from the Nordic mythology, themes which were hard to be assimilated by the Danish soldiers who, as Hans Kuhn points out, mostly entertained themselves with other, more down-to-earth songs. 18

While Grundtvig tried to embed the spirit of the Norse mythology into the new Danish society, some German authors were providing a different, rather pan-German-oriented interpretation of the stories of the Old North. Among them, those who had the widest and most long-lasting impact were with little doubt the Grimm brothers.

Jacob (1785-1863) and Wilhelm (1786-1859) Grimm's relationship with Denmark traces back to their years of youth, for the two brothers were

\footnotetext{
16 Nikolai Frederik Severin Grundtvig, N.F.S. Grundtvig: Schriften in Auswahl, German trans. Knud Evyin Bugge, Flemming Lundgreen-Nielsen, Theodor Jørgensen (Göttingen: Vandenhoeck \& Ruprecht GmbH \& Co., 2010), 264. The English translation is mine.

17 Elain F. Fain, “Nationalist Origins of the Folk High School: The Romantic Visions of N.F.S. Grundtvig", British Journal of Educational Studies, Vol. 19, No. 1 (1971), 70-90.

18 Hans Kuhn, “A Country Goes to War, Singing: Denmark in 1848" in 35th International Ballad Conference SIEF: Papers and Materials (2005, July 6-11, Kyiv, Ukraine) (Kyiv: National Academy of Science of Ukraine, Rylsky Institute for Art Studies, Folklore and Ethnology, 2009), 20-26.
} 
employed as clerks and later librarians for the County of Hesse and the short-lived Kingdom of Westphalia (1807-1813), two states which maintained close contacts with Copenhagen. ${ }^{19}$ The brothers' early love for the German past, which was nurtured by their early exposition to preRomantic cultural tendencies, soon developed into a scientific interest in the German cultural heritage as well as in the languages and cultures of the akin Scandinavians.

Jacob and Wilhelm approached Scandinavian antiquities both jointly (publication of the Edda in 1815) and separately, according to their personal interests and attitudes: Wilhelm, who was mostly interested in the Norse and Danish folk cultures, published a collection of traditional Danish ballads and tales translated into German, the valuable Altdänische Heldenlieder, Balladen und Märchen (1811); Jacob, more focussed on philology and linguistics, provided his own point of view on the Danish and other Scandinavian cultures in his Deutsche Grammatik (1819) and then in Deutsche Mythologie (1835).

Among these works, the Deutsche Grammatik was the one which stirred more problems. In fact, not only the Grammatik expands on the structure of German language, as the name suggests, but it also encompasses akin Germanic languages like Danish, Swedish, Norwegian, Gothic and Dutch: all these languages are here relentlessly labelled as Deutsch, thus expanding the German cultural space at the expenses of its linguistic relatives. ${ }^{20}$

Not surprisingly, Jacob Grimm's theories on Scandinavian languages met with some fierce opposition in Denmark, particularly by the great philologist Rasmus Rask (1787-1832). Rask and the Grimm brothers had been in epistolary communication since 1811, although they were already aware of each other's work. ${ }^{21}$ Rask's studies on the Indo-European languages had a great influence on Jacob's elaboration of what is today known as the Grimm's Law,22 i.e. the characteristic consonant shift taking place in the Germanic languages, and Jacob largely drew information from Rask's studies on Icelandic and Anglo-Saxon for the drafting of his

\footnotetext{
19 Cay Dollerup, Tales and Translation: The Grimm Tales from Pan-Germanic Narratives to Shared International Fairytales (Amsterdam/Philadelphia: John Benjamins Publishing, 1999), 10.

${ }^{20}$ Hans Frede Nielsen, "Jacob Grimm and the 'German' Dialects" in Elmer H. Antonsen, James W. Marchand, Ladislav Zgusta (eds.), The Grimm Brothers and the Germanic Past (Amsterdam/Philadelphia: John Benjamins Publishing,1990), 25.

${ }^{21}$ Dollerup, Tales and Translation, 15-20.

22 Hermann Collitz, “A Century of Grimm's Law”, Language, Vol. 2, No. 3 (1926): 174-183.
} 
Grammatik. ${ }^{23}$ Nonetheless, the mutual personal respect did not prevent Rask from firmly rebuking Jacob's pan-German approach to the study of the old and new Scandinavian languages, maintaining that their grammar and vocabulary were way too distant from German's. ${ }^{24} \mathrm{He}$ saw and denounced the clear relationship between Jacob's broad use of the term Deutsch and his German patriotism ${ }^{25}$ - patriotism which found its ultimate embodiment in his political career.

In fact, linguistics was not the only field where Jacob showed his panGerman fervour. On the occasion of the first Schleswig crisis in 1848, Jacob openly declared his support to the duchies and urged the Parliament to declare war to Denmark at the Frankfurt Parliament where he was serving as a member. In his heated speech, Grimm justified his position on the basis of his year-long studies of Nordic antiquities by which he came to the conclusion that the inhabitants of the peninsula of Jutland were originally of pure German stock, ${ }^{26}$ thus being Jutland entitled to become part of the German nation.

The debate over the German nature the inhabitants of Jutland, a crucial point in the intellectual justification of the Prussian aims at SchleswigHolstein, was also heavily influenced by the then-contemporary developments in the field of runology, the discipline devoted to the study of the runic alphabets. The case which particularly stirred up the animosity between Danish and German philologists was the interpretation of the fifteenth sign of the Germanic runic alphabet, the so-called algiz-rune ( $Y$ ). $19^{\text {th }}$-century runic scholars waved between the pronunciation of this sign as ' $\mathrm{m}$ ' or ' $\mathrm{r}$ ' (the latter being nowadays regarded as the correct one). This problem, which at first sight should have remained restricted within the philological circles, assumed a deep political relevance as German runic scholars like Karl Müllenhoff (1818-1884) saw the ' $m$ ' pronunciation as consistent with the development of the German language, therefore supporting the view of the Jutland runic relics as an early form of proto-

\footnotetext{
${ }^{23}$ Jacob Grimm, Deutsche Grammatik, 2nd edition (Göttingen, 1822), 1:XX, 22, 28, 239, 252, 292 etc.

${ }^{24}$ Nielsen, "Jacob Grimm and the 'German' Dialects", 25-26.

25 Arnold, Thor, 120. Nielsen: “Jacob Grimm and the 'German' Dialects”, 26.

26 "Jacob Grimm urges a declaration of war against Denmark over the Schleswig-Holstein in the 1848 Frankfurt Parliament", Stenographischer Bericht über die Verhandlungen der Deutschen Constituirenden Nationalversammlung zu Frankfurt am Main (Frankfurt, 1848-1850), 1: 289-90, http:/ / www.spinnet.eu/writings, accessed at 26.03.2013.
} 
German rather than proto-Norse. ${ }^{27}$ On the other side of the fence, Danish philologists struggled to demonstrate that the pronunciation of the algizrune had nothing to do with the early stages of German, but it was rather a distinctive feature of the old Nordic languages. This argument was taken on, among the others, by the prominent Danish linguist Ludvig Frands Adalbert Wimmer (1839-1929), who demonstrated that this rune is actually the graphic representation of an ' $r$ ' sound stemming the ancient Norse ' $\mathrm{z}$ ' sound, thus definitively separating it from any possible German-oriented rendition. ${ }^{28}$ As Elmer Antonsen points out, 'the interpretation of the $15^{\text {th }}$ rune as a kind of "r-sound" can be understood in the light of the history of runic studies and of the political history of the $19^{\text {th }}$ century." 29

\section{Schleswig Wars and Romantic German Intellectuals as Precursors of National Socialism?}

From the end of World War II on, some scholars have blamed German Romanticism for having provided an ideological antecedent to Nazi Germany's aggressive nationalism. Such a position has been strongly advocated by Leni Yahil: in her comparative analysis of $19^{\text {th }}$-century Danish and German nationalism, 30 she presented the theoretical foundation of Nazi Germany as the natural outcome of the nationalist ideas of Ernst Moritz Arndt (1769-1860) and Johann Gottlieb Fichte (1762-1814), whereas Nikolai Grundtvig is portrayed as an almost angelical figure benignly watching over the democratic development of Denmark:

Fichte said that he despaired of the German people in their present situation, as of mankind as a whole. In a mental salto mortale, he turned his despair into a utopian vision of a new mankind the Germans would build. Little did he know or imagine that his desire to arouse the people from their defeatism would be used to justify the Germans' hubris and their ambition to conquer the world. No less dangerous were his pedagogic assumptions. Fichte was not the only

\footnotetext{
27 For a overview of the history of the scholarly debate over the algiz-rune, see Elmer $\mathrm{H}$. Antonsen, Runes and German Linguistic (Berlin/New York: Mouton de Gruyter, 2002), 73-92. 28 Antonsen, Runes and German Linguistic, 81.

29 Antonsen, Runes and German Linguistic, 83.

30 Leni Yahil: "National Pride and Defeat: A Comparison of Danish and German Nationalism", Journal of Contemporary History, Vol. 26, No. 3/4, The Impact of Western Nationalisms: Essays Dedicated to Walter Z. Laqueur on the Occasion of His 70th Birthday (1991), 453-478.
} 
one who tried to rectify human nature and attain lofty goals by coercing the human will. Grundtvig's perception was the exact opposite: nothing could be changed completely. On the contrary, one had to start with the normal human condition of family ties and first experiences of life and only then try to develop in the young their inherent potential. Thus, in a completely free manner, real human intercourse would grow and true responsibility of the individual for himself and for the community would develop. [...] When Grundtvig became 'un-German', he said that he "gave up the German desire to shape the whole world according to my concept." 31

Yahil does not go as far as Daniel Jonah Goldhagen who controversially attempted to explain the Holocaust in the light of an alleged Christian and German genocidal mindset. ${ }^{32}$ Nonetheless, her depiction of German Romanticism does suggest that the German thinkers of the ' 800 were the actual intellectual forerunners of the atrocities of the '900. Her narrative presents a contraposition between an already aggressive, Nazilike German nationalism opposed to the modern, neutral, open-minded national consciousness of the Danes. Indeed, Yahil does have some good points while bringing up some of the most controversial aspects of Arndt's and Fichte's philosophy, but such a black-and-white picture of German and Danish nationalism prevents her from realising that her beloved Grundtvig too was a brilliant outcome of that German Romantic tradition she despises so much: the positive influence that German and Danish intellectuals had on each other as well as the more progressive and liberal aspect of German Romanticism are totally overlooked by Yahil in favour of a radical depiction of Denmark and Germany as two sealed-off and irremediably mutually hostile worlds. ${ }^{33}$

Such a black-and-white reading of German Romanticism had already been denounced as "over-simple" by Isaiah Berlin in his 1965's study on Herder's thought. ${ }^{34}$ Without denying the connection between $19^{\text {th }}$-century

${ }^{31}$ Leni, "National Pride and Defeat", 474-475.

32 Daniel Jonah Goldhagen, Hitler's Willing Executioners: Ordinary Germans and the Holocaust (New York: Vintage Books, 1997).

33 For a more recent (and more balanced) comparison of Grundtvig and Fichte's thought see Per Øhrgaard, "Fichte and Grundtvig as Educators of People", in John A. Hall, Ove Korsgaard, Ove K. Pedersen (eds.), Building the Nation: N.F.S. Grundtvig and Danish National Identity (Montreal: McGill-Queen's University Press, 2015), 213-231.

34 Isaiah Berlin, “J. G. Herder", Encounter, Vol. 25, No. 1 (July 1965), 29-48, No. 2 (August 1965), 42-51. 
German culture and some of its most unfortunate developments, Berlin has pointed out the richness and variety of the Romantic thought - a thought whose consequences cannot only be reduced to fascist ideologies:

... it is an historical and moral error to identify the ideology of one period with its consequences at some other, or with its transformation in another context and in combination with other factors. ${ }^{35}$

Joep Leerssen too has been undoubtedly less drastic than Yahil in analysing the work of Jacob Grimm, but he too has acknowledged that some aspects of Grimm's thought actually paved the way to harsher forms of German nationalism. Grimm's political activism during the Schleswig Wars is the obvious consequence, for Leerssen, of Jacob's own idea of nationalism, an idea where language is synonym to nationality: where German language is spoken, there is German people. ${ }^{36}$ This approach led Grimm to the conclusion that those German or Germanic people who at a certain point of their history ceased to speak their original tongue in order to adopt the language (often a neo-Latin one) of the lands they settled in went through a process of degeneration (Entartung) - a word which eventually was fully embedded in Nazi terminology. Leerssen refrains from directly associating Grimm with such a terminology, but does nonetheless pin down his responsibility for having used such a raciallycharged word:

Do I read too much into Grimm's use of an incidental word? I do not think so. Grimm, as a philologist, was always strongly aware of the root meaning of the words he used, and although he is altogether innocent of the phraseology of the Third Reich, he did testify to a sense that it is despicable and corrupt to compromise racial and linguistic purity. $\mathrm{He}$ felt, for instance, that Jews had no role to play in the philological cultivation of German language. ${ }^{37}$

In my opinion, Berlin and Leerssen have formulated the most convincing approach to such a delicate topic. In fact, if overlooking the

\footnotetext{
35 Berlin, "J. G. Herder", July, 44. Also cited in Fain, "Nationalist Origins of the Folk High School", 73. Fain too has criticised the Herder-to-Hitler paradigm.

36 Joep Leerssen, National Thought in Europe: A Cultural History (Amsterdam: Amsterdam University Press, 2006), 177-185.

37 Leerssen, National Thought in Europe, 207.
} 
most problematic aspects of Romantic thought would be pretty naive, it would be just as naive and over-simplistic to interpret National Socialism as the natural outcome of German Romanticism, even though the rising of Nazi Germany was admittedly the consequence of historical processes well rooted to the previous century. Such an ahistorical reading does not do justice to the complexity of the German Romantic thought as well as to its multiple outcomes: in fact, as we have stated before, the tolerant and moderate $19^{\text {th }}$-century Danish national thought may be well regarded, pace Yahil, as the fortunate offspring of German Romanticism in the Nordic lands.

\section{Conclusion}

The 19th-century debate between Danish and German intellectuals was influenced by and somewhat influenced the Schleswig Wars. The peculiar status of the duchies had made them a suitable buffer zone between the kingdom of Denmark and the German lands for many centuries. The emergence of nationalism on both sides ${ }^{38}$ altered this balance, first leading to the rebellion of the duchies against Copenhagen, and then to their ultimate loss for the Danish commonwealth. Nationalism has also been the element which contributed to polarise the positions between Danish and German intellectuals: in fact, whereas discussing the sound shift among consonants or the pronunciation of a long-forgotten rune, Danish and German scholars were actually arguing over the position of the Scandinavian cultural space vis-à-vis the German one. ${ }^{39}$ However, despite the polarisation caused by the political situation, the Danish-German debate cannot be reduced to a simple black-and-white contraposition. On the contrary, moments of tensions alternated with times when a high degree of cooperation existed between Danes and Germans. Ideas travelled freely across the borders, and both sides were deeply affected by the

\footnotetext{
38 It is worth noticing here that the same century which saw the cultural and military struggle between Danes and Germans also saw a strong contraposition between Danes and Norwegians, with the Norwegians standing up for their own political and cultural rights vis-à-vis Copenhagen. See Andreas Elviken's old but still informative "The Genesis of Norwegian Nationalism", The Journal of Modern History, Vol. 3, No. 3 (Sep., 1931), pp. 365391. See also Hroch's analysis of the Norwegian national movement, Social Preconditions of National Revival in Europe, 33-43.

39 Arnold, Thor, 120, 123.
} 
intellectual contributions coming from their foreign counterparts, as clearly shown in the case of Rask and Jacob Grimm.

In the end, even though the political conflict between Denmark and Prussia/Germany led to the incorporation of Schleswig, Holstein and Lauenburg into what was soon to become a unified German state, Danish scholars managed nonetheless to keep the Nordic cultures safe from panGerman reinterpretations of Scandinavian history and linguistic. ${ }^{40}$

\section{References:}

\section{Books and Articles}

Elmer H. Antonsen, Runes and German Linguistic (Berlin/New York: Mouton de Gruyter, 2002)

Martin Arnold, Thor: Myth to Marvel (London/New York: Continuum International Publishing Group, 2011).

Steffen Auring, Søren Baggesen, Finn Hauberg Mortensen, Søren Petersen, Marie-Louise Svane, Erik Svendsen, Poul Aaby Sørensen, Jørgen Vogelius, Martin Zerlang, Dansk litteraturhistorie 5: Borgerlig enhedskultur 1807-48 (1984, reprint Copenhagen: Gyldendal, 2000).

Isaiah Berlin, "J. G. Herder", Encounter, Vol. 25, No. 1 (July 1965), 29-48, No. 2 (August 1965), 42-51.

Edvard Beyer (ed.), Norges litteraturhistorie. Bind 2: Fra Wergeland til Vinje (1975, reprint Oslo: J.W. Capellens Forlag, 1995).

William Carr, Schleswig-Holstein 1815-1848: A Study in National Conflict (Manchester: Manchester University Press, 1963).

Hermann Collitz, “A Century of Grimm's Law”, Language, Vol. 2, No. 3 (1926), 174-183.

\footnotetext{
40 The fact that the knowledge of the Old North's culture has eventually strayed from the traditional Scandinavian and German cultural milieus may come off as an ironic conclusion of the 19th-century intellectual polemics. Superhero comics and films, political movements, music, videogames: the contemporary reinterpretation of images, themes and characters belonging to the Nordic cultures is a process largely happening outside the traditional Scandinavian cultural space: if the latter, in its Danish embodiment, and the German cultural space happened to clash over the heritage of the Old North, the object of their quarrel eventually grew out of them and became a firm part of what is today's Western (and possibly global) pop culture.
} 
Cay Dollerup, Tales and Translation: The Grimm Tales from Pan-Germanic Narratives to Shared International Fairytales (Amsterdam/Philadelphia: John Benjamins Publishing, 1999).

Andreas Elviken, "The Genesis of Norwegian Nationalism", The Journal of Modern History, Vol. 3, No. 3 (Sep., 1931), pp. 365-391.

Elain F. Fain, "Nationalist Origins of the Folk High School: The Romantic Visions of N.F.S. Grundtvig", British Journal of Educational Studies, Vol. 19, No. 1 (1971), 70-90.

Edgar Joseph Feuchtwanger, Bismarck (London/New York: Routledge, 2002).

Alexa Geisthövel, Eigentümlichkeit und Macht. Deutscher Nationalismus 18301851: Der Fall Schleswig-Holstein (Stuttgart: Franz Steiner Verlag, 2003).

Mircea-Cristian Ghenghea, "About Pan-Scandinavianism. Reference Points in the 19th Century(1815-1864)", Revista Română de Studii Baltice și Nordice / The Romanian Journal for Baltic and Nordic Studies, Vol. 6, Issue 2 (2014): pp. 127-145.

Daniel Jonah Goldhagen, Hitler's Willing Executioners: Ordinary Germans and the Holocaust (New York: Vintage Books, 1997).

Jacob Grimm, Deutsche Grammatik, 2nd edition (Göttingen, 1822).

Nikolai Frederik Severin Grundtvig, N.F.S. Grundtvig: Schriften in Auswahl, German trans. Knud Evyin Bugge, Flemming Lundgreen-Nielsen, Theodor Jørgensen (Göttingen: Vandenhoeck \& Ruprecht GmbH \& Co., 2010).

Ib Fischer Hansen, Jens Anker Jørgensen, Knud Michelsen, Jørgen Sorensen, Lars Tonnesen (eds.), Litteraturhåndbogen (1985, reprint Copenhagen: Nordisk Forlag, 1992).

Miroslav Hroch, Social Preconditions of National Revival in Europe: A Comparative Analysis of the Social Composition of Patriotic Groups among the Smaller European Nations, trans. Ben Fawkes (Cambridge: Cambridge University Press, 1985).

Helmut Georg Koenigsberger, "Composite States, Representative Institutions and the American Revolution", Historical Research 62 (1989), 135-53.

Hans Kohn, The Idea of Nationalism: A Study in Its Origins and Background (1944, reprint New Brunswick: Transaction Publishers, 2008). 
Hans Kuhn, "A Country Goes to War, Singing: Denmark in 1848” in 35 th International Ballad Conference SIEF: Papers and Materials (2005, July 611, Kyiv, Ukraine) (Kyiv: National Academy of Science of Ukraine, Rylsky Institute for Art Studies, Folklore and Ethnology, 2009).

Joep Leerssen, National Thought in Europe: A Cultural History (Amsterdam: Amsterdam University Press, 2006).

Hans Frede Nielsen, "Jacob Grimm and the 'German' Dialects" in Elmer H. Antonsen, James W. Marchand, Ladislav Zgusta (eds.), The Grimm Brothers and the Germanic Past, (Amsterdam/Philadelphia: John Benjamins Publishing,1990).

Per Øhrgaard, "Fichte and Grundtvig as Educators of People", in John A. Hall, Ove Korsgaard, Ove K. Pedersen (eds.), Building the Nation: N.F.S. Grundtvig and Danish National Identity (Montreal: McGillQueen's University Press, 2015), 213-231.

W. K. Stewart, "Oehlenschlæger and German Romanticism", Publications of the Society for the Advancement of Scandinavian Study, Vol. 2, No. 1 (October, 1914), 1-24.

Leni Yahil: "National Pride and Defeat: A Comparison of Danish and German Nationalism", Journal of Contemporary History, Vol. 26, No. 3/4, The Impact of Western Nationalisms: Essays Dedicated to Walter Z. Laqueur on the Occasion of His 70th Birthday (1991), 453478.

\section{On-Line Sources}

"Jacob Grimm urges a declaration of war against Denmark over the Schleswig-Holstein in the 1848 Frankfurt Parliament", Stenographischer Bericht über die Verhandlungen der Deutschen Constituirenden Nationalversammlung zu Frankfurt am Main (Frankfurt, 1848-1850), 1: 289-90, http://www.spinnet.eu/writings, accessed at 26.03.2013. 